\title{
Management of Brackish Water for Crop Production in Two Different Textured Soils
}

\author{
Amar Iqbal Saqib, Khalil Ahmed*, Muhammad Khalid Bhatti, Ghulam Qadir, Muhammad Qaisar Nawaz, \\ Muhammad Ashfaq Anjum, Abdul Rasul Naseem, Aftab Ahmad Sheikh and Belqees Akhter
}

Soil Salinity Research Institute (SSRI), Pindi Bhattian, Pakistan.

\begin{abstract}
In Pakistan, renewable freshwater resources are decreasing due to unpredictable rainfall changes and farming community is compelled to use underground brackish water. Therefore, a lysimetric study was undertaken to remediate hazardous effects of brackish water on rice-wheat crops through practicable and economical methods in two different textured soils. Treatments were: (A) Types of soils. 1) sandy loam, 2) clay loam, (B) Remedial strategies, 1). canal water, 2) saline-sodic tube well water (continuous), 3) three irrigations of tube well water and two of canal water in a cyclic manner (short cyclic use), 4) tube well water + gypsum @ RSC of water, 5) tube well water+ canal water in 1:1 ratio (conjunctive use). Data showed that the highest biomass and paddy/grain yield were produced by canal water $\left(\mathrm{T}_{1}\right)$ followed by $\left(\mathrm{T}_{3}\right)$ where three irrigations of tube well water and two of canal water were used in a short cyclic manner. Whereas, growth and yield of rice and wheat crops were significantly reduced by continuous use of brackish water $\left(\mathrm{T}_{2}\right)$ and maximum $\mathrm{pH}_{\mathrm{s}}, \mathrm{EC}_{\mathrm{e}}$ and $\mathrm{SAR}$ were noted in this treatment in both textured soils. Different management practices (use of gypsum and blending) also mitigated the ill effects of saline-sodic water. Therefore, it was concluded that when fresh-water resources are finite and use of saline-sodic water is inevitable, cyclic use of canal and saline-sodic water is a wise and profitable management strategy with marginal effect on crop productivity and proves least detrimental for soil health. Comparison of two different textured soils also revealed that brackish water deteriorated the soil properties of clay loam soil more in comparison to sandy loam soil that highlighted the primary role of soil texture for salinity development and must be recognized while using the brackish water for irrigation purpose.

Received | October 06, 2020; Accepted | June 29, 2021; Published | July 08, 2021

*Correspondence | Khalil Ahmed, Soil Salinity Research Institute (SSRI), Pindi Bhattian, Pakistan; Email: khalilahmeduaf@gmail.com

Citation | Saqib, A.I., K. Ahmed, M.K. Bhatti, G. Qadir, M.Q. Nawaz, M.A. Anjum, A.R. Naseem, A.A. Sheikh and B. Akhter. 2021.

Management of brackish water for crop production in two different textured soils. Pakistan Journal of Agricultural Research, 34(3): 614-624.

DOI | https://dx.doi.org/10.17582/journal.pjar/2021/34.3.614.624

Keywords | Texture, Sandy loam, Clay loam, Brackish water, Rice, Wheat
\end{abstract}

\section{Introduction}

$\mathrm{C}$ ompetition among agricultural, industrial, and municipal sectors dwindled the allocation of freshwater resources to the agriculture sector (Tilman et al., 2002). This situation is expected to exacerbate in foreseeable future in countries of arid to semiarid climate like Pakistan, which already have been suffering from climatic changes (Qadir and Oster,
2004). As the supplies of fresh water resources are expected to diminish in the future and the supply of canal water is unpredictable, farmers installed tube wells as a more secure and extra water supply resource which can contribute to the reliability of food production and improve livelihoods of the farmers. However, this reliability on the usage of groundwater is threatening the health of soil and crop productivity because $70-80 \%$ of pumped water is brackish (Latif 
and Beg, 2004). High evapotranspiration rate, due to the semi-arid climate of Pakistan, resulted in the net upward movement and accumulation of soluble salts in surface soil which may develop a saline area of $3 \times 10^{6}$ ha in the country (Rafiq, 1990). Therefore, successful and secure use of underground brackish water with efficient and suitable management practices is one of the most relevant approach to overcome the problem of secondary salinity (FAO, 1999; Oster, 2000), which will allow the farmers to use this valuable water resource for their crop productivity. Therefore, the development of an effective irrigation mode using the limited canal water and adequate underground brackish water is necessary to achieve the economical and allowable yield of field crops without adverse effects on soil properties.

Different researchers in the field experiment demonstrated that use of fresh and brackish water is feasible through blending or cyclic mode. In the cyclic mode of irrigation, fresh water and brackish water are used separately while in blending manner, both waters are used simultaneously (Qureshi et al., 2004). Cyclic mode of irrigation could maintain the crop productivity without buildup of toxic salts in surface soil if freshwater irrigation was used before sowing (Verma et al., 2012). Moreover, blending, or cyclic modes of irrigation may result in the relative yield up to 80-98\% (Verma et al., 2014). Li et al. (2019) opined that under fresh water shortage conditions, application of non-saline water at the seedling and flowering stage while saline-water application at fruit set-stage was the most suitable mode of irrigation for high yield production of tomato without deteriorating the soil properties. Gandahi et al. (2017) concluded from a pot experiment that cotton gave the economical yield if six irrigations were provided with saline water and six irrigations with non-saline water in a conjunctive manner. Similarly, Chen et al. (2018) suggested that the optimal mixing of nonsaline and saline water may be more beneficial for cotton production and avoid secondary salinization when using saline water.

Continuous use of saline-sodic water without any suitable amendment might result in accumulation of the toxic soluble salts, lowering the crop productivity, and deteriorating the soil properties (Mandare et al., 2008; Wang et al., 2015). The choice of suitable remedial strategy to control the salinization problem by brackish water depends on several factors such as type of the selected crop, the salinity of brackish water, crop growth stage, cultural practices, and chemical amendment. Sodicity problem of brackish water may be tackled by the application of some proper amendment e.g., calcium chloride, gypsum (Gupta and Gupta, 1997). Chaudhary et al. (2003) stated that gypsum reduced the ill effect of drainage water, while drainage water without gypsum application significantly affected the yield of cotton and wheat crops. They stated that cyclic use of drainage and canal water had lesser ill effects on soil properties and crop productivity than the continuous use of drainage water alone. Murtaza et al. (2006) concluded that gypsum and FYM applications neutralized the detrimental effects of saline-sodic water and produced the maximum grain and straw yield of wheat which was non-significant with canal water and cyclic use of brackish water and canal water.

Soil texture is one of the most important factors which determines how brackish water affects the soil properties. Different textured soils are affected differently by the same concentration of salt in brackish water, generally, light-textured soils (sandy soils) show the least ill effect of brackish water as compared to heavy textured (clay) soils. Yadav (1982) noted that saline water $\left(8.0 \mathrm{dS} \mathrm{m}^{-1}\right)$ reduced the yield of wheat in sandy loam soil whereas the same crop was unable to grow in clayey soil with saline water of $4.0 \mathrm{dS} \mathrm{m} \mathrm{m}^{-1}$. According to Chaudhary et al. (1983), brackish water having $\mathrm{RSC}<2 \mathrm{me} \mathrm{L}^{-1}, \mathrm{EC}=3.2 \mathrm{dS}$ $\mathrm{m}^{-1}$ and SAR $\left.<5(\mathrm{mmol} \mathrm{L})^{-1}\right)^{1 / 2}$ could be used safely for sandy loam soil than clay loam. They also observed that wheat yield reduction was more in fine textured soil than on coarse textured soil. Similar observation was also noted by Abid et al. (2003) that brackish water affects the wheat yield more negatively in clay soil than sandy textured soil.

Considering the previous research, the present study was planned to assess the effects of different remedial strategies to alleviate the ill effect of brackish water used to irrigate rice and wheat crops in two different textured soils.

\section{Materials and Methods}

This study was conducted at Soil Salinity Research Institute Pindi Bhattian, Hafizabad. Treatments were: (A) Types of soils. 1) sandy loam, 2) clay loam, (B) Remedial strategies, 1). canal water, 2) saline-sodic 
tube well water (continuous), 3) three irrigations of tube well water and two of canal water in a cyclic manner (short cyclic use), 4) tube well water + gypsum @ RSC of water, 5) tube well water + canal water in 1:1 ratio (conjunctive use). Two different textured soils, sandy loam and clay loam were selected and filled in lysimeter $(180 \mathrm{~cm}$ length $\times 120 \mathrm{~cm}$ width $\times 90 \mathrm{~cm}$ height). The experimental was conducted in factorial arrangement with completely randomized design having three repeats. Rice-wheat crop rotation was used for two years. Gypsum was applied in every Kharif season, thirty days before transplantation of rice in respective lysimeter. During the first Kharif season, thirty days old seedlings of rice (Shaheen Basmati) were transplanted in lysimeter. Fertilizers at the rates of $\mathrm{N} 110, \mathrm{P} 90$, and $\mathrm{K} 60 \mathrm{~kg} \mathrm{ha}^{-1}$ was used for rice crop. All the treatments were employed according to treatment plan and plant protection measures and agronomical practices were carried out uniformly. Rice crop was harvested at maturity and data about biomass and paddy yield were documented. During the Rabi season, in the same layout, fertilizers at the rates of $\mathrm{N} 120, \mathrm{P} 110$, and $\mathrm{K} 70 \mathrm{~kg} \mathrm{ha}^{-1}$ were applied and wheat (Inqlab-91) was sown directly in the soil. The crop was irrigated according to the treatment plan throughout the growth season. At physical maturity, data about biomass and grain yield were documented. At the end of study, soil samples were collected and analyzed for $\mathrm{pH}_{\mathrm{s}}, \mathrm{EC}_{\mathrm{e}}$ and SAR (U.S. Salinity Laboratory Staff, 1954). The same treatments and pattern of rice-wheat was replicated for the second year. The collected crop data were subjected to statistically analysis. The treatment mean comparison was made using Least Significant Difference Test @ 5\% probability level (Steel et al., 1997) using STATISTIX 8.1 package software.

Table 1: Physical and chemical properties of the study soils.

\begin{tabular}{|c|c|c|}
\hline Parameters & Sandy loam & Clay loam \\
\hline Sand \%age & 70 & 44 \\
\hline Silt \%age & 13 & 26 \\
\hline Clay \%age & 17 & 30 \\
\hline $\mathrm{pH}_{\mathrm{s}}$ & 8.06 & 8.10 \\
\hline $\mathrm{EC}_{\mathrm{e}}\left(\mathrm{dS} \mathrm{m}^{-1}\right)$ & 1.28 & 1.35 \\
\hline $\mathrm{SAR}\left(\mathrm{mmol} \mathrm{L}{ }^{-1) 1 / 2}\right.$ & 3.15 & 3.35 \\
\hline Organic matter \% & 0.62 & 0.78 \\
\hline Available $\mathrm{K} \mathrm{mg} \mathrm{kg}^{-1}$ & 90 & 110 \\
\hline Available P mg kg-1 & 6.80 & 7.20 \\
\hline
\end{tabular}

Table 2: Analysis of irrigation waters.

$\begin{array}{llll}\text { Parameters } & \begin{array}{c}\text { Brackish } \\ \text { Water }\end{array} & \begin{array}{l}\text { Blended } \\ \text { Water }\end{array} & \begin{array}{l}\text { Canal } \\ \text { Water }\end{array} \\ \mathrm{EC}_{\mathrm{iw}}\left(\mathrm{dS} \mathrm{m}^{-1}\right) & 2.72 & 1.62 & 0.32 \\ \mathrm{SAR}\left(\mathrm{mmol} \mathrm{L}^{-1}\right)^{1 / 2} & 23.85 & 11.35 & 0.53 \\ \operatorname{RSC}\left(\mathrm{me} \mathrm{L}^{-1}\right) & 5.8 & 2.70 & \text { Nil }\end{array}$

\section{Results and Discussion}

\section{First year}

Data in Table 3 illustrated that during the first year, rice biomass and paddy yield was affected significantly $(p<0.05)$ by different management strategies. On the mean value basis, maximum biomass $\left(22.72 \mathrm{t} \mathrm{ha}^{-1}\right)$ and paddy yield (3.44 $\mathrm{t} \mathrm{ha}^{-1}$ ) were produced by canal water $\left(\mathrm{T}_{1}\right)$, followed by cyclic mode of irrigation $\left(\mathrm{T}_{3}\right)$ with biomass and paddy yield of 16.53 and $2.67 \mathrm{tha}^{-1}$ respectively. While continuous use of saline-sodic $\left(\mathrm{T}_{2}\right)$ water negatively affected the biomass and paddy yield of the rice crop and lowest biomass (12.40 t $\left.\mathrm{ha}^{-1}\right)$ and paddy yield $\left(2.16 \mathrm{t} \mathrm{ha}^{-1}\right)$ were divulged in this treatment. The use of gypsum and blending of canal and tube well water (1:1 ratio) also remained significant than the continuous use of saline-sodic water. Comparison of two different textured soils also showed a significant difference with respect to biomass and paddy yield. In heavy textured soil (clay loam), significantly higher biomass (17.49 $\left.\mathrm{t} \mathrm{ha}^{-1}\right)$ and paddy yield $\left(2.74 \mathrm{t} \mathrm{ha}^{-1}\right)$ were recorded than light textured soil (sandy loam). Interaction between treatments and textured also showed significant differences in rice biomass and paddy yield. Maximum biomass and paddy yield was produced in clay loam soil with canal water irrigation. Whereas, the continuous irrigation with brackish water alone significantly decreased the biomass and paddy yield in both types of soils.

Table 3: Effect of different remedial strategies and brackish water on biomass and paddy yield of first rice crop in two different textured soils $\left(t h \mathrm{a}^{-1}\right)$.

\begin{tabular}{|c|c|c|c|c|c|c|}
\hline \multirow{2}{*}{$\begin{array}{l}\text { Treat- } \\
\text { ments }\end{array}$} & \multicolumn{3}{|c|}{ Biomass yield $\left(\mathrm{t} \mathrm{ha}^{-1}\right)$} & \multicolumn{3}{|c|}{ Paddy yield $\left(\mathrm{t} \mathrm{ha}^{-1}\right)$} \\
\hline & $\begin{array}{l}\text { Sandy } \\
\text { loam }\end{array}$ & $\begin{array}{l}\text { Clay } \\
\text { loam }\end{array}$ & Mean & $\begin{array}{l}\text { Sandy } \\
\text { loam }\end{array}$ & $\begin{array}{l}\text { Clay } \\
\text { loam }\end{array}$ & Mean \\
\hline $\mathrm{T}_{1}$ & $16.52 \mathrm{c}$ & $28.92 \mathrm{a}$ & $22.72 \mathrm{a}$ & $2.75 \mathrm{c}$ & $4.12 \mathrm{a}$ & $3.44 \mathrm{a}$ \\
\hline $\mathrm{T}_{2}$ & $12.40 \mathrm{~d}$ & $12.40 \mathrm{~d}$ & $12.40 \mathrm{~d}$ & $1.69 \mathrm{~g}$ & $1.64 \mathrm{~g}$ & $2.16 \mathrm{~d}$ \\
\hline $\mathrm{T}_{3}$ & $12.40 \mathrm{~d}$ & $20.66 \mathrm{~b}$ & $16.53 \mathrm{~b}$ & 2.05 ef & $3.29 \mathrm{~b}$ & $2.67 \mathrm{~b}$ \\
\hline $\mathrm{T}_{4}$ & $8.26 \mathrm{f}$ & $8.96 \mathrm{c}$ & $8.61 \mathrm{e}$ & $1.76 \mathrm{~g}$ & $2.19 \mathrm{e}$ & $1.98 \mathrm{e}$ \\
\hline $\mathrm{T}_{5}$ & $12.40 \mathrm{~d}$ & $16.53 \mathrm{c}$ & $14.47 \mathrm{c}$ & $1.95 \mathrm{f}$ & $2.47 \mathrm{~d}$ & $2.21 \mathrm{c}$ \\
\hline Mean & $12.39 \mathrm{~b}$ & $17.49 \mathrm{a}$ & & $2.04 \mathrm{~b}$ & $2.74 \mathrm{a}$ & \\
\hline
\end{tabular}

Means sharing the same letters are statistically similar at $p \leq 0.05$. 
Data regarding the wheat crop also showed a similar trend, different remedial strategies and soil texture affected the growth performance of wheat crop (Table 4). Continuous use of brackish water alone significantly reduces the biomass and grain yield as compared to other treatments and recorded the lowest biomass $\left(8.29 \mathrm{t} \mathrm{ha}^{-1}\right)$ and grain yield (3.02 t $\mathrm{ha}^{-1}$ ). Whereas different management practices (canal water, gypsum, blending, and cyclic use) significantly improved the biomass and grain yield. Maximum biomass (12.99 $\left.\mathrm{tha}^{-1}\right)$ and grain yield $\left(4.80 \mathrm{t} \mathrm{ha}^{-1}\right)$ were produced with canal water irrigation $\left(T_{1}\right)$ followed by $T_{3}$ and $T_{4}$ where cyclic mode of irrigation and gypsum were used. Biomass yield was also affected by the texture of soils and maximum biomass (11.12 $\mathrm{t} \mathrm{ha} \mathrm{a}^{-1}$ ) was produced in clay loam soil. Maximum grain yield (4.05 $\mathrm{t} \mathrm{ha}^{-1}$ ) was also produced by clay loam soil, however, it was at par with grain yield produced in sandy loam soil. Interaction among the soil texture and remedial strategies showed that canal water irrigation in clay loam soil produced maximum biomass and grain yield while brackish water alone in both types of soils showed a significant reduction in these attributes.

Table 4: Effect of different remedial strategies and brackish water on biomass and grain yield of first wheat crop in two different textured soils $\left(t h a^{-1}\right)$.

\begin{tabular}{llllllll} 
Treat- & \multicolumn{3}{c}{ Biomass yield $\left(\mathbf{t h a}^{-1}\right)$} & \multicolumn{3}{c}{ Grain yield $\left(\mathbf{t ~ h a}^{-1}\right)$} \\
ments & $\begin{array}{l}\text { Sandy } \\
\text { loam }\end{array}$ & $\begin{array}{l}\text { Clay } \\
\text { loam }\end{array}$ & Mean & \multicolumn{2}{l}{$\begin{array}{l}\text { Sandy } \\
\text { loam }\end{array}$} & $\begin{array}{l}\text { Clay } \\
\text { loam }\end{array}$ & Mean \\
$\mathrm{T}_{1}$ & $12.42 \mathrm{~b}$ & $13.57 \mathrm{a}$ & $12.99 \mathrm{a}$ & $4.63 \mathrm{~b}$ & $4.96 \mathrm{a}$ & $4.80 \mathrm{a}$ \\
$\mathrm{T}_{2}$ & $8.46 \mathrm{f}$ & $8.12 \mathrm{f}$ & $8.29 \mathrm{~d}$ & $3.12 \mathrm{f}$ & $2.91 \mathrm{f}$ & $3.02 \mathrm{~d}$ \\
$\mathrm{~T}_{3}$ & $10.48 \mathrm{de}$ & $11.40 \mathrm{c}$ & $10.94 \mathrm{~b}$ & $4.15 \mathrm{~cd}$ & $4.21 \mathrm{~cd}$ & $4.18 \mathrm{~b}$ \\
$\mathrm{~T}_{4}$ & 10.09 de & $11.68 \mathrm{bc}$ & $10.88 \mathrm{bc}$ & $3.98 \mathrm{cde}$ & $4.26 \mathrm{c}$ & $4.12 \mathrm{~b}$ \\
$\mathrm{~T}_{5}$ & $9.74 \mathrm{e}$ & $10.82 \mathrm{~cd}$ & $10.28 \mathrm{c}$ & $3.78 \mathrm{e}$ & $3.89 \mathrm{de}$ & $3.84 \mathrm{c}$ \\
Mean & $10.24 \mathrm{~b}$ & $11.12 \mathrm{a}$ & & $3.93 \mathrm{a}$ & $4.05 \mathrm{a}$ &
\end{tabular}

Means sharing the same letters are statistically similar at $p \leq 0.05$

\section{Second year}

Results of the second year showed that reduction in biomass and paddy/grain yield was more pronounced with continuous use of brackish water as compared to first year (Tables 5 and 6). Data about the secondyear rice crop revealed that the lowest yield of biomass (10.95 $\left.\mathrm{t} \mathrm{ha}^{-1}\right)$ and paddy yield $\left(1.97 \mathrm{t} \mathrm{ha}^{-1}\right)$ were observed in treatment $\left(\mathrm{T}_{2}\right)$ where brackish water alone was used for irrigation (Table 5). Whereas, maximum biomass (18.76 $\left.\mathrm{tha}^{-1}\right)$ and paddy yield (3.40 $\mathrm{t} \mathrm{ha} \mathrm{h}^{-1}$ ) were noted with canal water $\left(\mathrm{T}_{1}\right)$ followed by cyclic use of canal and brackish water $\left(\mathrm{T}_{3}\right)$. Addition of gypsum $\left(\mathrm{T}_{4}\right)$ and blending of canal and brackish water $\left(T_{5}\right)$ remained non-significant from each other. With respect to soil texture, clay loam soil produced maximum biomass (16.24 $\left.\mathrm{t} \mathrm{ha}^{-1}\right)$ and paddy yield $\left(2.84 \mathrm{t} \mathrm{ha}^{-1}\right)$ which differed significantly from the yield of sandy loam soil.

Table 5: Effect of different remedial strategies and brackish water on biomass and paddy yield of second rice crop in two different textured soils $\left(t h a^{-1}\right)$.

\begin{tabular}{lcllllll}
$\begin{array}{l}\text { Treat- } \\
\text { ments }\end{array}$ & \multicolumn{3}{c}{ Biomass yield $\left(\right.$ t ha $\left.^{-1}\right)$} & \multicolumn{3}{c}{ Paddy yield $\left(\mathbf{t ~ h a}^{-1}\right)$} \\
& $\begin{array}{l}\text { Sandy } \\
\text { loam }\end{array}$ & $\begin{array}{l}\text { Clay } \\
\text { loam }\end{array}$ & Mean & \multicolumn{2}{l}{$\begin{array}{l}\text { Sandy } \\
\text { loam }\end{array}$} & $\begin{array}{l}\text { Clay } \\
\text { loam }\end{array}$ & Mean \\
$\mathrm{T}_{1}$ & $16.70 \mathrm{c}$ & $20.84 \mathrm{a}$ & $18.76 \mathrm{a}$ & $3.00 \mathrm{c}$ & $3.80 \mathrm{a}$ & $3.40 \mathrm{a}$ \\
$\mathrm{T}_{2}$ & $10.91 \mathrm{f}$ & $11.00 \mathrm{f}$ & $10.95 \mathrm{~d}$ & $1.78 \mathrm{f}$ & $2.15 \mathrm{e}$ & $1.97 \mathrm{~d}$ \\
$\mathrm{~T}_{3}$ & $11.39 \mathrm{f}$ & $19.22 \mathrm{~b}$ & $15.31 \mathrm{~b}$ & $2.10 \mathrm{e}$ & $3.24 \mathrm{~b}$ & $2.63 \mathrm{~b}$ \\
$\mathrm{~T}_{4}$ & $12.09 \mathrm{e}$ & $16.36 \mathrm{c}$ & $14.23 \mathrm{c}$ & $2.05 \mathrm{e}$ & $2.58 \mathrm{~d}$ & $2.32 \mathrm{c}$ \\
$\mathrm{T}_{5}$ & $12.28 \mathrm{~d}$ & $13.77 \mathrm{~d}$ & $14.03 \mathrm{c}$ & $2.19 \mathrm{e}$ & $2.41 \mathrm{~d}$ & $2.30 \mathrm{c}$ \\
Mean & $13.07 \mathrm{~b}$ & $16.24 \mathrm{a}$ & & $2.21 \mathrm{~b}$ & $2.84 \mathrm{a}$ &
\end{tabular}

Means sharing the same letters are statistically similar at $p \leq 0.05$.

Table 6: Effect of different remedial strategies and brackish water on biomass and grain yield of second wheat crop in two different textured soils $\left(t h a^{-1}\right)$.

\begin{tabular}{|c|c|c|c|c|c|c|}
\hline \multirow{2}{*}{$\begin{array}{l}\text { Treat- } \\
\text { ments }\end{array}$} & \multicolumn{3}{|c|}{ Biomass yield $\left(\mathrm{t} \mathrm{ha}^{-1}\right)$} & \multicolumn{3}{|c|}{ Grain yield $\left(\mathrm{t} \mathrm{ha}^{-1}\right)$} \\
\hline & $\begin{array}{l}\text { Sandy } \\
\text { loam }\end{array}$ & $\begin{array}{l}\text { Clay } \\
\text { loam }\end{array}$ & Mean & $\begin{array}{l}\text { Sandy } \\
\text { loam }\end{array}$ & $\begin{array}{l}\text { Clay } \\
\text { loam }\end{array}$ & Mean \\
\hline $\mathrm{T}_{1}$ & $8.07 \mathrm{ab}$ & $8.51 \mathrm{a}$ & $8.29 \mathrm{a}$ & $3.29 \mathrm{~b}$ & $3.96 \mathrm{a}$ & $3.63 \mathrm{a}$ \\
\hline $\mathrm{T}_{2}$ & $6.63 \mathrm{ef}$ & $5.84 \mathrm{~g}$ & $6.24 \mathrm{c}$ & $2.54 \mathrm{~cd}$ & $2.45 \mathrm{~cd}$ & $2.50 \mathrm{~d}$ \\
\hline $\mathrm{T}_{3}$ & $7.15 \mathrm{de}$ & $7.83 \mathrm{bc}$ & $7.49 \mathrm{~b}$ & $3.01 \mathrm{bc}$ & $3.19 \mathrm{bc}$ & $3.10 \mathrm{~b}$ \\
\hline $\mathrm{T}_{4}$ & 6.70 de & $6.01 \mathrm{bg}$ & $6.36 \mathrm{c}$ & $2.64 \mathrm{c}$ & $2.62 c$ & $2.63 \mathrm{~cd}$ \\
\hline $\mathrm{T}_{5}$ & $7.30 \mathrm{~cd}$ & $7.14 \mathrm{de}$ & $7.22 \mathrm{~b}$ & $2.75 \mathrm{c}$ & $2.88 \mathrm{bc}$ & $2.82 \mathrm{bc}$ \\
\hline Mean & $7.17 \mathrm{a}$ & $7.66 \mathrm{a}$ & & $2.85 \mathrm{a}$ & $3.02 \mathrm{a}$ & \\
\hline
\end{tabular}

Means sharing the same letters are statistically similar at $p \leq 0.05$

Interaction among the treatments and soil texture revealed that maximum biomass and paddy yield was divulged in clay loam soil irrigated with canal water and minimum biomass and paddy yield was recorded in sandy loam soil irrigated with brackish water.

Data regarding the second-year wheat crop showed that maximum mean value for biomass $\left(8.29 \mathrm{t} \mathrm{ha}^{-1}\right)$ and grain yield $\left(3.63 \mathrm{t} \mathrm{ha}^{-1}\right)$ were noted with canal water which differed significantly from cyclic use mode of irrigation. On the contrary, the lowest mean value for grain $\left(2.50 \mathrm{tha}^{-1}\right)$ and biomass $(6.24 \mathrm{tha}$ 1) were recorded with brackish water irrigation. Soil texture did not show the significant effect on biomass 
and grain yield and both parameters remained nonsignificant during the second year. The interactive effect of treatments and soil texture displayed that maximum grain and biomass yield was observed with canal water irrigation in clay loam soil. On the other hand, minimum grain and biomass yield was observed with brackish water irrigation in sandy loam soil.

\section{Soil properties}

Data regarding the soil properties showed that continuous use of brackish water increased the final $\mathrm{pH}_{\mathrm{s}}, \mathrm{EC}_{\mathrm{e}}$ and $\mathrm{SAR}$ in both soil texture. However, the application of different remedial strategies lowered the increasing trend of $\mathrm{pH}_{s}, \mathrm{EC}_{e}$, and SAR. Soil texture affected the final value of soil $\mathrm{pH}_{\mathrm{s}}$. Sandy loam soil showed an increase of $8.43 \%$ while clay loam showed an increase of $8.51 \%$ in final soil $\mathrm{pH}_{\mathrm{s}}$ with respect to their initial values in the treatment where brackish water was used continuously (Table 7).

Soil $\mathrm{EC}_{\mathrm{e}}$ was also affected by soil texture and remedial strategies, maximum $\mathrm{EC}_{\mathrm{e}}$ was developed by brackish water which was $267 \%$ and $237 \%$ over their initial values in clay loam and sandy loam soils, respectively (Table 8). Data regarding soil SAR revealed that brackish water irrigation showed an increase of $681 \%$ and $654 \%$ with respect to their initial values in clay loam and sandy loam soils, respectively (Table 9).

Shortage of freshwater resources in Pakistan due to climatic change, compelling the farmers to use underground brackish water, which results in loss of crop productivity and deteriorates the soil health. However, site-specific management practices may be employed to counteract the hazardous effects of poor-quality water. Therefore, in present work, different remedial strategies were tested to alleviate the detrimental effects of brackish water on rice and wheat crops in two different textured soils. Results showed that consistent use of saline-sodic water alone adversely affected the growth and yield of rice and wheat crops and negative effects were more pronounced in second years. Reduction in paddy/grain and biomass yield due to brackish water without any proper management strategy may be explained that accumulation of toxic salts in the rhizosphere exerts the phenomenon of specific ion toxicity, osmotic effect, and nutritional imbalance (Munns, 1993; Amirjani, 2011; Pessarakli, 2016). Soil analysis at the end of the study clearly demonstrated that salinity and sodicity indicators i.e., $\mathrm{EC}_{\mathrm{e}}$ and $\mathrm{SAR}$ increased significantly where saline-sodic water was used alone, resultantly, this development of secondary salinity adversely affected the crop growth.

Table 7: Effect of different remedial strategies and brackish water on soil $p H$ at the end of study in two different textured soils.

$\begin{array}{lllll}\text { Treatments } & \begin{array}{l}\text { Sandy } \\ \text { loam }\end{array} & \begin{array}{l}\text { \% increase over } \\ \text { initial value }\end{array} & \begin{array}{l}\text { Clay } \\ \text { loam }\end{array} & \begin{array}{l}\text { \% increase over } \\ \text { initial value }\end{array} \\ \mathrm{T}_{1} \text { Canal water } & 8.09 & 0.37 & 8.09 & 0.12 \\ \mathrm{~T}_{2} \text { Saline sodic tube well water (continuous) } & 8.74 & 8.43 & 8.79 & 8.51 \\ \mathrm{~T}_{3} \text { Three irrigations of tube well water and two of canal } & 8.38 & 3.97 & 8.39 & 3.58 \\ \text { water in cyclic manner } & & & & \\ \mathrm{T}_{4} \text { Tube well water + gypsum @ RSC of water } & 8.34 & 3.47 & 8.35 & 3.08 \\ \mathrm{~T}_{5} \text { Tube well water+ canal water in 1:1 ratio } & 8.49 & 5.33 & 8.53 & 5.30\end{array}$

Table 8: Effect of different remedial strategies and brackish water on soil $E C_{e}$ at the end of study in two different textured soils.

$\begin{array}{lllll}\text { Treatments } & \begin{array}{l}\text { Sandy } \\ \text { loam }\end{array} & \begin{array}{l}\text { \% increase over } \\ \text { initial value }\end{array} & \begin{array}{l}\text { Clay } \\ \text { loam }\end{array} & \begin{array}{l}\text { \% increase over } \\ \text { initial value }\end{array} \\ \mathrm{T}_{1} \text { Canal water } & 1.70 & 32 & 1.68 & 24 \\ \mathrm{~T}_{2} \text { Saline sodic tube well water (continuous) } & 4.32 & 237 & 4.96 & 267 \\ \mathrm{~T}_{3} \text { Three irrigations of tube well water and two of canal } & 3.40 & 165 & 3.76 & 178 \\ \text { water in cyclic manner } & & & & \\ \mathrm{T}_{4} \text { Tube well water + gypsum @ RSC of water } & 3.54 & 176 & 3.78 & 180 \\ \mathrm{~T}_{5} \text { Tube well water+ canal water in 1:1 ratio } & 3.58 & 179 & 4.04 & 199\end{array}$


Table 9: Effect of different remedial strategies and brackish water on soil SAR ( mmol $\left.L^{-1}\right)^{1 / 2}$ at the end of study in two different textured soils.

$\begin{array}{lllll}\text { Treatments } & \begin{array}{l}\text { Sandy } \\ \text { loam }\end{array} & \begin{array}{l}\text { \% increase over } \\ \text { initial value }\end{array} & \begin{array}{l}\text { Clay } \\ \text { loam }\end{array} & \begin{array}{l}\text { \% increase over } \\ \text { initial value }\end{array} \\ \mathrm{T}_{1} \text { Canal water } & 7.74 & 145 & 9.02 & 169 \\ \mathrm{~T}_{2} \text { Saline sodic tube well water (continuous) } & 23.78 & 654 & 26.18 & 681 \\ \mathrm{~T}_{3} \text { Three irrigations of tube well water and two of canal } & 14.89 & 372 & 15.82 & 372 \\ \text { water in cyclic manner } & & & & \\ \mathrm{T}_{4} \text { Tube well water + gypsum @ RSC of water } & 12.92 & 310 & 13.22 & 294 \\ \mathrm{~T}_{5} \text { Tube well water+ canal water in 1:1 ratio } & 18.10 & 474 & 19.58 & 484\end{array}$

The use of poor-quality water reduced the number of tillers, leaf area, and biomass production in rice crop (Castillo et al., 2007). Salinity stress before the heading reduced the number and weight of panicle in rice crop (Zeng and Shannon, 2003). Saline water may reduce the grain yield by $47 \%$ in wheat crop (Singh, 2004). Similarly, brackish water with $\mathrm{EC}_{\text {iw }}$ of 1.5, 2.0, and $2.85\left(\mathrm{dS} \mathrm{m}^{-1}\right)$ decreased the wheat grain yield by 7,5 and $13 \%$, respectively (Chaudhary et al., 1986). According to Hamdy et al. (2005), saline water having the $\mathrm{EC}_{\mathrm{iw}}$ of $9 \mathrm{dS} \mathrm{m} \mathrm{m}^{-1}$ reduced wheat grain yields up to $25 \%$ in comparison to canal water treatment. Current results are in agreement with the earlier findings that the productivity of many agronomical crops affected negatively by the brackish water (Chaudhary et al., 2001; Avais et al., 2018; Qadir et al., 2019). Salt stress in rice crop before the heading reduced the number and weight of panicle during the period of three leaf stage until booting (Zeng and Shannon, 2003). Further, at flowering stage, salt stress adversely affected the photosynthesis which resulted in the formation of unfilled spikelet and ultimately the number of filled grains in the panicle decreased (Moradi, 2002; Zhang et al., 2015). Brackish water salinity results in reducing biomass, leaf area, number of tillers, delay in flowering, and ripening in rice crop (Kavosi, 1995; Castillo et al., 2007).

However, at the same time, different remedial strategies (cyclic use, blending, and use of gypsum) alleviated the ill effects of saline-sodic water. Biomass and paddy/grain yield produced with remedial strategies were in between the canal water and brackish water. The basic principle of growing the agronomical crops is that the salts level in rhizosphere must be under the safe limits than the threshold level of that crop (Maas and Hoffman, 1977; Munns and Tester, 2008). In this perspective: blending, cyclic use of brackish, and canal water or use of any amendment like gypsum are very effective strategies to reduce the root zone salinity. In the current study, remedial strategies also produced a better yield of rice and wheat crop than brackish water alone which may be explained due to their favorable effects on soil properties like dilution of ionic contents in soil solution (Minhas et al., 2007), improved $\mathrm{Ca}^{2+}: \mathrm{Na}^{+}$ratio (Minhas et al., 2007; Kahlon, 2011), and improved water content (Huang et al., 2015). Results of post-harvest soil analysis also supported the better yield of crops in these treatments because the use of gypsum, blending or cyclic use mode of irrigation reduced the development of secondary salinity. Sekhon et al. (2019) in 5 years field study demonstrated that blending of good quality water having RSC $=0.6 \mathrm{mmol}_{c} \mathrm{~L}^{-1}$ and $\mathrm{EC}$ $=0.45 \mathrm{dS} \mathrm{m}^{-1}$ with poor quality water having RSC $=6.44 \mathrm{mmol} \mathrm{L}^{-1}$ and $\mathrm{EC}=2.22 \mathrm{dS} \mathrm{m}^{-1}$ in $1: 1$ ratio on loamy sand soil is a very reasonable and feasible strategy to produce the tuber yield of potato under water shortage scenario. Wang et al. (2019) concluded that fresh water, followed by brackish water, and then fresh water is a very effective technique for the growth of wheat crop without affecting the physiological processes of the crop. Furthermore, with this strategy, salt accumulation and water conservation were maintained without the significant loss in soil health. Use of gypsum to mitigate the detrimental effect of poor-quality water may increase the wheat grain yield up to $12 \%$ (Chaudhary et al., 2004) while rice yield affected negatively by drainage water without the use of gypsum (Qadir et al., 1996) that reinforced the present results.

Soil texture also had a pronounced specific effect on growth and yield of rice and wheat crops. Rice paddy and biomass yield was significantly affected by the texture of soil during both years while for the wheat crop, this effect was not significant. Improved yield in clay loam soil as compared to sandy loam may be explained by the improved nutritional status of clay loam soil (Table 2). Soil with more clay content 
retained more organic matter, mineral nutrients, and water contents (Six et al., 2000; Dou et al., 2016) which produced more favorable growth conditions for crop growth. On contrary, sandy soils retained less nutrients and provided easier passage for water removal and consequently, unable to fulfill the nutrient and water demand of plant, especially at the grain development stage (Dou et al., 2016). Comparable findings were described by Tsubo et al. (2007) that rice grown in heavy textured soil produced more biomass and paddy yield than those grown in light textured soil. Zhang et al. (2012) also stated that rice crop produced more panicles in clay soil than sandy soil. Rao et al. (2013) also observed a large variation in spikelet panicle ${ }^{-1}$ of rice crop which may range from 43 to 198, depending upon soil texture. Jalota et al. (2010) also observed the higher yield of wheat and maize crops in silt loam than loamy sand and sandy loam which may be explained due to more water holding capacity of silt loam soil. Significant effect of soil texture on rice yield and yield attributes was also reported by Dou et al. (2016). They reported that rice grain yield and number of panicles were $46 \%$ and $25 \%$ higher in clay soil than sandy loam soil.

Soil properties were affected substantially by different remedial strategies and brackish water. Quantity and quality of water with respect to soluble salts are very important for irrigation purpose (Sekhon et al., 2019). Blending and cyclic use modes of irrigation water caused the less development of secondary salinity, a plausible reason was the dilution effect (Sekhon et al., 2019).

Blending of brackish water with good quality water in $1: 1$ ratio or their cyclic use produced the favorable growth conditions by improving the infiltration rate and lowering the soil SAR, ESP, $\mathrm{pH}$ and bulk density (Choudhary and Ghuman, 2008; Choudhary et al., 2011). Minhas et al., (2007) stated that mixing of good quality water with higher alkaline water or cyclic use resulted in the lower value of soil ESP. Soil texture also has primary importance in assessing the development of secondary salinity. Comparison of two soil texture revealed that the chemical properties of heavy textured soil were deteriorated more as compared to light textured soil using saline-sodic water. A plausible reason for more deteriorated properties in clay loam soil may be due to the clay dispersion, migration and clogging of soil pores which appeared to cause the problem of increasing bulk density and poor infiltration rate and ultimately the soil properties are adversely affected (Grattan and Oster, 2003). Coarse textured soils mostly contained macro pores and low cation exchange capacity whereas, fine textured soils possess micro pores filled with water and high cation exchange capacity. Therefore, salt removed in less quantity and higher value of SAR and $\mathrm{EC}_{\mathrm{e}}$ was noted in fine textured soil as compared to coarse textured soil (Mirza and Zia, 2006; Mostafazadeh-Fard et al., 2008; Kahlon, 2011). Comparable results are stated by different researchers that brackish water irrigation increased the contents of soluble salts in heavy textured soils and their properties were adversely affected by brackish water as compared to medium textured soil (Ma et al., 2007; Farooq, 2009; Kahlon, 2011).

\section{Conclusions and Recommendations}

Conclusively, results showed that growth and yield of rice and wheat crops were significantly reduced by the continuous use of brackish water, however, different management practices can be used to mitigate the adverse effects of brackish water which would permit the expansion and sustainability of irrigated agriculture. When freshwater resources are finite and use of poor-quality water is inevitable, cyclic use of saline-sodic and canal water is a wise and profitable management strategy with a marginal effect on crop productivity and proves least detrimental for soil health. Comparison of two different textured soils revealed that brackish water deteriorated the soil properties of clay loam soil more than sandy loam soil that highlighted the primary role of soil texture for salinity development which must be considered while using the brackish water for irrigation purpose.

\section{Novelty Statement}

when fresh-water resources are finite and use of saline-sodic water is inevitable, cyclic use of canal and saline-sodic water is a wise and profitable management strategy with marginal effect on crop productivity and proves least detrimental for soil health.

\section{Author's Contribution}

Amar Iqbal Saqib, Khalil Ahmed, conceived the idea, conducted the study for two years, Khalil Ahmed, and Ghulam Qadir, wrote abstract and materials and methods, Muhammad Qaisar Nawaz, Muhammad Khalid Bhatti, did data collection and statistical 
analysis, Abdul Rasul Naseem, Muhammad Ashfaq Anjum, Aftab Ahmad Sheikh, Belqees Akhter provided technical Input at every step.

\section{Conflict of interest}

The authors have declared no conflict of interest.

\section{References}

Abid, M., A. Hassan, A. Ghafoor and K. Javed. 2003. Brackish water for irrigation: safe levels of $\mathrm{EC}_{\mathrm{iw}}, \mathrm{SAR}_{\mathrm{iw}}$ and RSC for crop grown on different soil series. Pak. J. Soil Sci. 22: 55-63.

Amirjani, M.R., 2011. Effect of salinity stress on growth, sugar content, pigments, and enzyme activity of rice. Int. J. Bot., 7: 73-81. https://doi. org/10.3923/ijb.2011.73.81

Avais, M.A., Q. Ghulam, A. Khalil, I. Muhammad, I.S. Amar, A.W. Imtiaz, Q.N. Muhammad, S. Muhammad, and A. Muhammad. 2018. Role of inorganic and organic amendments in ameliorating the effects of brackish water for Raya-Sunflower production. Int. J. Biosci., 12: 117-122.

Castillo, E.G., T. Phuc, M.A. Abdelbaghi and I. Kazuyuki. 2007. Response to salinity in rice: Comparative effects of osmotic and Ionic stress. Plant Prod. Sci., 10(2): 159-170. https://doi. org/10.1626/pps.10.159

Chaudhary, M.R., M. Iqbal and K.M. Subhani. 2001. Management of brackish water: Impact on soil and crops. Pak. J. Soil Sci., 20: 33-38.

Chaudhary, M.R., M. Iqbal and K.M. Subhani. 2003. Use of brackish drainage water effluent for crop production, 9th International Drainage Workshop, September 10-13, 2003, Utrecht (The Netherlands).

Chaudhary, M.R., M. Iqbal. and K.M. Subhani. 2004. Use of poor-quality drainage water for crop production and its impact on soil. Pak. J. Water Resour., 8 (1): 1-8.

Chaudhary, M.R., M.S. Rafique, H. Ali, and L.A. Shahid. 1986. Soil properties and crop yield as affected by different water salinity levels. Pak. J. Soil Sci., 10: 42-50.

Chaudhry, H.G., M. Sadiq, A. Hameed, and I. Ullah. 1983. Effect of moisture and water salinity levels on soil properties and crop yield. Mona Rec. Exp. Project, Bhalwal, Pakistan. Publ. No. 128, pp. 1-35.

Chen, W., J. Menggui, P.A.F. Ty, L. Yanfeng,
X. Yang, S. Tianrui and P. Xue. 2018. Spatial distribution of soil moisture, soil salinity, and root density beneath a cotton field under mulched drip irrigation with brackish and fresh water. Field Crops Res., 215: 207-221. https:// doi.org/10.1016/j.fcr.2017.10.019

Choudhary, O.P. and B.S. Ghuman. 2008. Cyclic use of sodic and non-sodic canal waters for irrigation in cotton-wheat cropping system in a semi-arid region. J. Sust. Agric., 32(2): 269-286. https://doi.org/10.1080/10440040802170939

Choudhary, O.P., S.R. Grattan and P.S. Minhas. 2011. Sustainable crop production using saline and sodic irrigation waters. Altern. Farm. Syst., Biotechnol. Drought Stress Ecol. Fertil., pp. 293-318. https://doi.org/10.1007/978-94-0070186-1_10

Dou, F., S. Junel, E.T. Rodante and C. Kun. 2016. Soil texture and cultivar effects on rice (oryza sativa, L.) grain yield, yield components and water productivity in three water regimes. PLoS One, 11(3): 1-12. https://doi.org/10.1371/ journal.pone.0150549

FAO, 1999. The future of our land: Facing the challenge. Guidelines for integrated planning for sustainable management of land resources. FAO and UNEP, Rome

Farooq,M.R., 2009. Sustainable crop production by using brackish water. $\mathrm{Ph}$. D. thesis. University of Agriculture, Faisalabad Pakistan.

Gandahi, A.W., A. Kubar, M.S. Sarki, N. Talpur and M. Gandahi.2017. Response of conjunctive use of fresh and saline water on growth and biomass of cotton genotypes. J. Basic App. Sci., 13: 326-334. https://doi.org/10.6000/19275129.2017.13.54

Grattan, S.R. and J.D. Oster. 2003. Use and reuse of saline-sodic waters for irrigation of crops. J. Crop Prod., 7: 131-162. https://doi. org/10.1300/J144v07n01_05

Gupta, S.K. and I.C. Gupta. 1997. Quality of irrigation water. P. 71-98. In: Management of Saline Soils and Waters. Sci. Publ., Jodhpur, India.

Hamdy, A., V. Sardo and K.A. Farrag. 2005. Saline water in supplemental irrigation of wheat and barley under rain fed agriculture. Agric. Water Manage., 78: 122-127. https://doi. $\mathrm{org} / 10.1016 /$ j.agwat.2005.04.017

Huang, J.O., M.G. Jin and X.W. Li. 2015. Effects of alternative irrigation with brackish and fresh 
water on cotton yields and solute transport in soil. Trans. Chinese Soc. Agric. Eng., 31: 99107 (in Chinese, with English abstract).

Jalota, S.K., S. Sukhvinder, G.B.S. Chahal, S.S. Ray, S. Panigraghy, B. Singh and K.B. Singh. 2010. Soil texture, climate, and management effects on plant growth, grain yield, and water use by rainfed maize-wheat cropping system: Field and simulation study. Agric. Water Manage. 97: 83-90. https://doi.org/10.1016/j. agwat.2009.08.012

Kahlon, U.Z., 2011. Effects of amendments and irrigation water composition on salt leaching from different textured soils and amelioration of saline sodic soils for crop production. $\mathrm{Ph}$. D. thesis. University of Agriculture, Faisalabad Pakistan.

Kavosi, M., 1995. The best model to rice yield prediction in salinity condition. Dissertation of M. Sc. Tabriz University.

Latif, M. and A. Beg. 2004. Hydrosalinity issues, challenges, and options in OIC member states. In: M. Latif, S. Mahmood, and M.M. Saeed, eds. Proceedings of the International Training Workshop on Hydrosalinity Abatement and Advance Techniques for Sustainable Irrigated Agriculture, September 20-25, 2004. PCRWR, Islamabad. pp. 1-14.

Li, J., C. Jing, Q. Zhongyi, W. Shaoli, H. Pingru and Z.Na.2019. Effects of alternating irrigation with fresh and saline water on the soil salt, soil nutrients, and yield of tomatoes. Water, 11: 2-19. https://doi.org/10.3390/w11081693

Ma, W., Z. Mao and Z. Yu. 2007. Effects of saline water irrigation on soil salinity and yield of winter wheat-maize in North China Plain. Irri. Drain. Syst. 22(1): 3-18. https://doi. org/10.1007/s10795-007-9027-1

Maas, E.V., and G.J. Hoffman. 1977. Crop salt tolerance-current assessment. J. Irrig. Drain. Div., 103: 115-134. https://doi.org/10.1061/ JRCEA4.0001137

Mandare, A.B., S.K. Ambast, N.K. Tyagi and J. Singh. 2008. On-farm water management in saline groundwater area under scarce canal water supply condition in northwest India. Agric. Water Manage. 95(5): 516-526. https:// doi.org/10.1016/j.agwat.2007.12.010

Minhas, P.S., S.K. Dubey and D.R. Sharma. 2007. Comparative effects of blending, intera/interseasonal cyclic uses of alkali and good quality waters on soil properties and yields of paddy and wheat. Agric. Water Manage., 87: 83-90. https://doi.org/10.1016/j.agwat.2006.06.003

Mirza, B.B. and M.S. Zia. 2006. Rehabilitation of problem soils through environmentally friendly technologies - II: Role of sesbania (Sesbania aculeata) and gypsum. Agric. Trop. Subtrop., 39: 26-33.

Moradi, F., 2002. physiological characterization of rice cultivars for Salinity tolerance during vegetative and reproductive stages. $\mathrm{Ph}$. $\mathrm{D}$. thesis. University of Philippines, Los Banos. Philippines.

Mostafazadeh, B.F., M. Heidarpour, A. Aghakhani and M. Feizi. 2008. Effects of leaching on soil desalinization for wheat crop in arid region. Plant Soil Environ., 54: 20-29. https://doi. org/10.17221/2780-PSE

Munns, R. and M. Tester. 2008. Mechanisms of salinity tolerance. Ann. Rev. Plant Biol., 59: 651-681. https://doi.org/10.1146/annurev. arplant.59.032607.092911

Munns, R., 1993. Physiological processes limiting plant growth in saline soil: Some dogmas and hypotheses. Plant Soil Environ., 16: 15-24. https://doi.org/10.1111/j.1365-3040.1993. tb00840.x

Murtaza, G., A. Ghafoor and M. Qadir. 2006. Irrigation and soil management strategies for using saline-sodic water in a cotton-wheat rotation. Agric. Water Manage., 81: 98-114. https://doi.org/10.1016/j.agwat.2005.03.003

Oster, J.D., 2000. Irrigation sustainability. In: Proceedings of the Sixth International MicroIrrigation Congress, 22-27 October 2000. Cape Town. ICID-CIID. Plenary Session, P6. CD Rom. Document Transformation Technologies, POB 560, Lirene, 0062, South Africa

Pessarakli, M., 2016. Handbook of photosynthesis, third ed. CRC Press Florida, Taylor and Francis Publishing Group. pp. 846. https://doi. org/10.1201/b19498

Qadir, G., A. Khalil, I.S. Amar, I. Muhammad, Q.N. Muhammad, S. Muhammad and M. Zaheen. 2019. Sustainable use of brackish water for cotton wheat rotation. Asian J. Agric. Biol., 7(4): 593-601.

Qadir, M., G. Murtaza and A. Ghafoor. 1996. Use of agricultural drainage water for crop production in the fourth drainage project area. Pak. J. Soil Sci., 2: 22-26. 
Qadir. M. and J.D. Oster. 2004. Crop and irrigation management strategies for saline-sodic soils and water aimed at environmentally sustainable agriculture.Sci.TotalEnviron.,323:1-19.https:// doi.org/10.1016/j.scitotenv.2003.10.012

Qureshi, A.S., H. Turral and I. Masih. 2004. Strategies for the management of conjunctive use of surface water and groundwater resources in semi-arid areas: A case study from Pakistan. Research Report 86. Colombo, Sri Lanka: IWMI.

Rafiq, M., 1990. Soil resources and soil related problems in Pakistan. Soil Physics application under stress environment. In: M. Ahmad, M. E. Akhtar and M. I. Nizami, Editors, Proceedings of the Symposium on Applied Soil Physics in Stress Environment, Islamabad, 22-26 January, BARD Project PARC, Islamabad (1989), pp. 16-23.

Rao, P.R., D. Subrhamanyam, B. Sailaja, R.P. Singh, V. Ravichandran and G.V.S. Rao. 2013. Influence of boron on spikelet fertility under varied soil conditions in rice genotypes. J. Plant Nutr., 36: 390-400. https://doi.org/10.1080/01 904167.2012 .744420

Sekhon, K.S., K. Anureet, T. Sudhir, A.S. Sidhua, N. Garga, O.P. Choudharyb, G.S. Buttarc and C. Neena. 2019. Irrigation water quality and mulching effects on tuber yield and soil properties in potato (Solanum tuberosum L.) under semi-arid conditions of Indian Punjab. Field Crops Res. Article in press. https://doi. org/10.1016/j.fcr.2019.06.001

Singh, R.K., K.N. Singh, B. Misra, S.K. Sharma, and N.K. Tyagi. 2004. Harnessing plant salt tolerance for overcoming sodicity constraints. In: Advances in Sodic Land Reclamation, International Conference on Sustainable Management of Sodic Lands, 9-14 February 2004, Lucknow, India, pp. 81-120.

Six, J., K. Paustian, E.T. Elloitt and C. Combrink. 2000. Soil structure and soil organic matter, I. distribution of aggregate size classes and aggregate associated carbon. Soil Sci. Soc. Am. J., 64: 681-689. https://doi.org/10.2136/ sssaj2000.642681x

Steel, R.G.D., J.H. Torrie and D.A. Dickey. 1997. Principles and Procedures of Statistic: A Biometrical Approach. Mc Graw Hill book Co. Inc. New York. $3^{\text {rd }}$ edition, pp. 400-428.

Tilman, D., K.G. Cassman, P.A. Matson, R. Naylor and S. Polasky. 2002. Agricultural sustainability and intensive production practices. Nature, 418: 671-677. https://doi.org/10.1038/nature01014

Tsubo, M., S. Fukai, J. Basnayake, T.P. Tuong, B. Bouman and D. Harnpichitvitaya. 2007. Effects of soil clay content on water balance and productivity in rainfed lowland rice ecosystem in northeast Thailand. Plant Prod. Sci., 10: 232241. https://doi.org/10.1626/pps.10.232

U.S. Salinity Lab. Staff. 1954. Diagnosis and Improvement of Saline and Alkali Soils. USDA Handbook 60, Washington DC, USA.

Verma, A.K., S.K. Gupta and R.K. Isaac. 2012. Long-term cyclic irrigation in subsurface drained lands: simulation studies with SWAP. J. Agric. Sci., 5(1): 84. https://doi.org/10.5539/ jas.v5n1p84

Verma, A.K., S.K. Gupta and R.K. Isaac. 2014. Calibration and validation of SWAP to simulate conjunctive use of fresh and saline irrigation waters in semiarid regions. Environ. Model. Assess., 19(1): 45-55. https://doi.org/10.1007/ s10666-013-9379-x

Wang, T., X. Zhenghe and P. Guibin. 2019. Effects of irrigating with brackish water on soil moisture, soil salinity, and the agronomic response of winter wheat in the yellow river delta. Sustainability, 11: 2-16. https://doi. org/10.3390/su11205801

Wang, X.P., J.S. Yang, G.M. Liu, R.J. Yao and S.P. $\mathrm{Yu}$. 2015. Impact of irrigation volume and water salinity on winter wheat productivity and soil salinity distribution. Agric. Water Manage., 149: 44-54.https://doi.org/10.1016/j. agwat.2014.10.027

Yadav, J.S.P., 1982. Use of saline ground water for irrigation. In Proceeding of the international symposium on salt-affected soils, p. 281-290. Karnal, India, CSSRI.

Zeng, L. and M.C. Shannon. 2003. Salinity effects on seedling growth and yield components of rice. Crop Sci., 40: 996-1003. https://doi. org/10.2135/cropsci2000.404996x

Zhang, J., Y.J. Lin, L.F.S.M. Zhu, Yu, K.K. Sanjoy and Q.Y. Jin. 2015. Effects of 1-methylcyclopropene on function of flag leaf and development of superior and inferior spikelets in rice cultivars differing in panicle types. Field Crops Res., 177: 64-74. https://doi. org/10.1016/j.fcr.2015.03.003

Zhang, X., Q. Dai, X. Hu, D. Zhu, X. Ding and 
K. Ma. 2012. Effects of slow-release urea combined with conventional urea on rice output and growth in soils of different textures. Acta Agric. Sinica, 38: 1494-1503. https://doi. org/10.3724/SP.J.1006.2012.01494 